\title{
Rigid Rodlike Dinuclear Ru/Os Complexes of a Novel Bridging Ligand. Intercomponent Energy and Electron-Transfer Processes
}

\author{
Vincenzo Balzani, ${ }^{1 \mathrm{a}}$ Francesco Barigelletti, ${ }^{1 \mathrm{~b}}$ Peter Belser, ${ }^{*}, 1 \mathrm{c}$ Stefan Bernhard, ${ }^{1 \mathrm{c}}$ \\ Luisa De Cola, ${ }^{*, 1 a}$ and Lucia Flamigni ${ }^{1 \mathrm{~b}}$ \\ Dipartimento di Chimica “G. Ciamician” Università di Bologna, 40126 Bologna, Italy, Istituto FRAE-CNR, \\ via P. Gobetti 101, 40129 Bologna, Italy, and Institut für Anorganische Chemie, Universität Fribourg, \\ Fribourg, Switzerland
}

Received: August 6, $1996^{\otimes}$

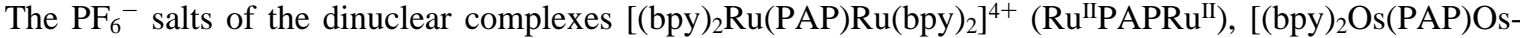
$\left.(\text { bpy })_{2}\right]^{4+}\left(\mathrm{Os}^{\mathrm{II} P A P O} \mathrm{~s}^{\mathrm{II}}\right)$, and $\left[(\mathrm{bpy})_{2} \mathrm{Ru}(\mathrm{PAP}) \mathrm{Os}(\mathrm{bpy})_{2}\right]^{4+}\left(\mathrm{Ru}^{\mathrm{II} P A P O}{ }^{\mathrm{II}}\right)$ have been prepared, where bpy $=$ $2,2^{\prime}$-bipyridine and PAP is a rodlike bridging ligand made of an adamantane-based spacer collinear with the coordination axis of two 1,10-phenanthroline units. In the prepared complexes, the metal-metal distance is $2.1 \mathrm{~nm}$. In the Ru${ }^{\mathrm{II} P A P O}{ }^{\mathrm{II}}$ compound, photoinduced energy transfer from the $\mathrm{Ru}^{\mathrm{II}}$-based to the Os ${ }^{\mathrm{II}}$-based unit takes place with rate constant $5.2 \times 10^{7} \mathrm{~s}^{-1}$ at room temperature and $2.4 \times 10^{7} \mathrm{~s}^{-1}$ at $77 \mathrm{~K}$. In the mixed-valence $\mathrm{Ru}^{\mathrm{II}} \mathrm{PAPO} \mathrm{s}^{\mathrm{III}}$ compound, the luminescent excited state of the $\mathrm{Ru}^{\mathrm{II}}$-based unit is quenched via

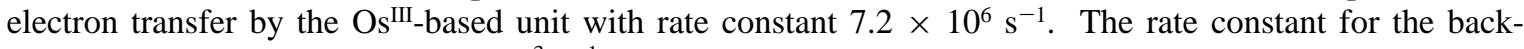
electron-transfer reaction is $8.3 \times 10^{3} \mathrm{~s}^{-1}$.
\end{abstract}

\section{Introduction}

Great attention is currently paid to the synthesis of polynuclear transition-metal complexes and the study of their photochemical, photophysical, and electrochemical properties. ${ }^{2}$ This interest is stimulated, in particular, by attempts to design and construct multicomponent systems (often called supramolecular species) capable to perform useful light- and/or redox-induced functions. ${ }^{3}$

In polynuclear complexes the metal-based components are linked together by bridging ligands (Figure 1a). The role played by the bridging ligands is extremely important for the following reasons: (i) with their coordinating sites they contribute to determine the spectroscopic and redox properties of the active metal-based units; (ii) their spacers and the connections between spacers and coordinating sites determine the structure of the supramolecular system; (iii) their chemical nature controls the electronic communication between the metal-based units. Therefore the choice of suitable bridging ligands is crucial to obtain polynuclear complexes capable to show luminescence, to exhibit interesting electrochemical properties, and to give rise to photoinduced energy- and electron-transfer processes.

A wide range of bridging ligands have been used in recent years. Many of them contain 2,2'-bipyridine (bpy), 1,10phenanthroline (phen), or 2,2':6'2'-terpyridine (tpy) as chelating units capable to coordinate $\mathrm{Ru}(\mathrm{II}) .^{2}$ From the photophysical viewpoint, bpy and phen are much better ligands than tpy for $\mathrm{Ru}(\mathrm{II})$. It is well-known, in fact, that at room temperature in fluid solution $\left[\mathrm{Ru}(\mathrm{bpy})_{3}\right]^{2+}$ and $\left[\mathrm{Ru}(\text { phen })_{3}\right]^{2+}$ exhibit a strong and long-lived luminescence ( $\tau$ of the order of $\left.10^{2}-10^{3} \mathrm{~ns}\right),{ }^{4}$ whereas $\left[\mathrm{Ru}(\text { tpy })_{2}\right]^{2+}$ is very weakly luminescent $(\tau$ ca. 0.25 ns). ${ }^{5}$ From the viewpoint of structure, however, the bridging ligands based on tpy are much more appealing since connection with a spacer can occur along the coordination axis by $4^{\prime}$-substitution yielding linear complexes (Figure 1b), a result that cannot be achieved by simple substitution on bpy and phen (Figure 1c,d). ${ }^{6}$

From the above discussion, it is clear that an ideal component to build linear, rodlike polynuclear complexes of photophysical

${ }^{\otimes}$ Abstract published in Advance ACS Abstracts, October 1, 1996.

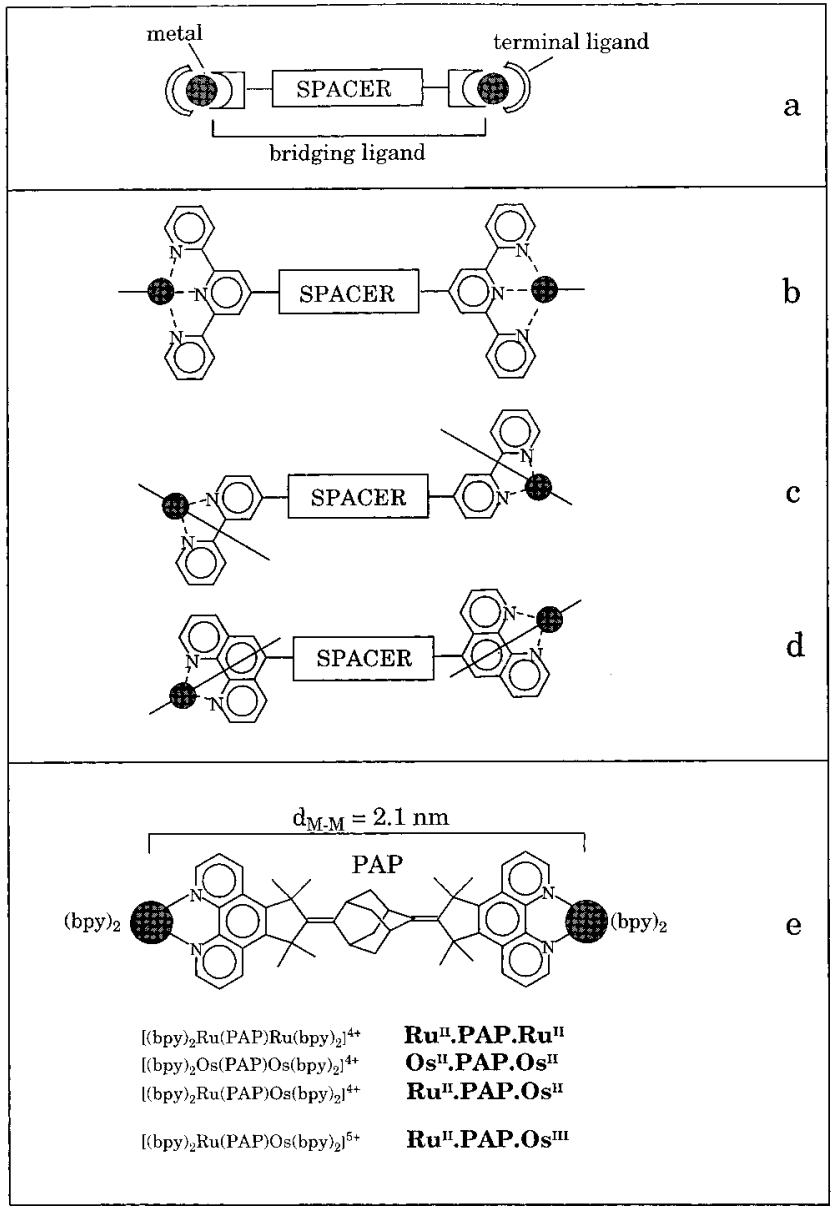

Figure 1. Schematic representation of a dinuclear complex (a), of the structures obtained by tpy (b), bpy (c), and phen (d) chelating units, and by the novel PAP bridging ligand (e). The abbrevations used to indicate the metal complexes are also shown.

interest would be a bridging ligand combining the linear structure based on $4^{\prime}$-substituted tpy chelating units with the electronic properties of bpy or phen. We have achieved this 


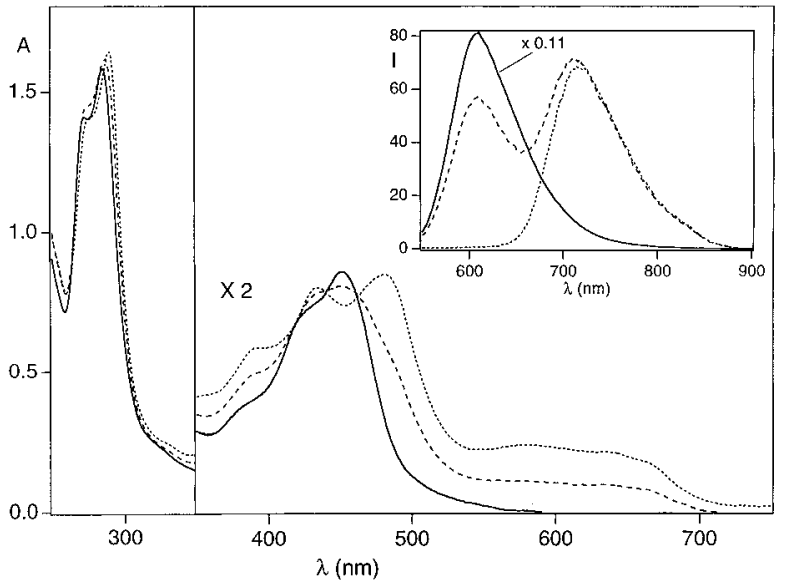

Figure 2. Absorption and (inset) emission spectra in acetonitrile solution at room temperature of $\mathrm{Ru}^{\mathrm{II} P A P R u^{\mathrm{II}}}(-), \mathrm{Ru}^{\mathrm{II}} \mathrm{PAPO}{ }^{\mathrm{II}}(---)$, and $\mathrm{Os}^{\mathrm{II}} \mathrm{PAPOs}^{\mathrm{II}}(\cdots)$.

goal by preparing the bridging ligand $\mathrm{PAP}^{7}$ (2,6-adamantanebis(1,1,3,3-tetramethyl-1,3-dihydro-7,8-diaza)cyclopenta[1]phenanthrene-2-ylidene) shown in Figure 1e. In this paper we report the luminescence properties of its dinuclear $\mathrm{Ru} / \mathrm{Ru}, \mathrm{Ru} /$ Os, and Os/Os complexes having bpy as terminal ligands (Figure $1 \mathrm{e})$ and the results of an investigation on intercomponent energyand electron-transfer processes.

\section{Experimental Part}

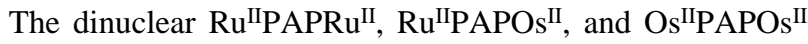
complexes were prepared and purified according to previously reported procedures. ${ }^{8}$ Characterization was performed by FAB mass spectrometry, and ${ }^{1} \mathrm{H}$ and ${ }^{13} \mathrm{C}$ NMR. The ${ }^{1} \mathrm{H}$ NMR

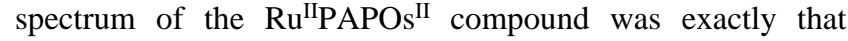
expected for the two independent metal-based moieties. Experiments were carried out in acetonitrile $(\mathrm{MeCN})$ solution at 298 $\mathrm{K}$ and in butyronitrile rigid matrix at $77 \mathrm{~K}$. The mixed-valence $\mathrm{Ru}^{\mathrm{II} P A P O}{ }^{\mathrm{III}}$ compound was obtained by oxidation with nitric acid in $\mathrm{MeCN}-\mathrm{H}_{2} \mathrm{O}$ (9:1) solution. The equipment used to measure the absorption spectra, luminescence spectra and lifetimes, transient absorption spectra, and redox potentials has also been previously described. ${ }^{8}$

\section{Results and Discussion}

The absorption spectra in $\mathrm{MeCN}$ at room temperature are

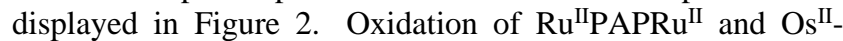
PAPOs $^{\mathrm{II}}$ occurs with bielectronic waves at +1.235 and +0.800 $\mathrm{V}$ (vs SCE), respectively, whereas Ru${ }^{\mathrm{II}}$ PAPOs ${ }^{\mathrm{II}}$ shows two monoelectronic waves at +1.240 and $+0.795 \mathrm{~V}$. These results show that each metal-based unit displays its own absorption spectrum and electrochemical properties, as expected in the case of very weak intercomponent interaction.

The emission spectra in MeCN at $298 \mathrm{~K}$ are displayed in the inset of Figure 2, and the luminescence data are gathered in Table 1. The luminescence properties of $\mathrm{Ru}^{\mathrm{II} P A P R u^{\mathrm{II}}}$ are very similar to those of $\mathrm{Ru}(\mathrm{bpy})_{2}(\text { phen })^{2+}\left(\lambda_{\max }=575 \mathrm{~nm}, \tau=6.6\right.$ $\mu \mathrm{s}$ in $\mathrm{MeOH} / \mathrm{EtOH}$ at $77 \mathrm{~K} ;{ }^{9} \lambda_{\max }=601 \mathrm{~nm}, \tau=310 \mathrm{~ns}$ in $\mathrm{CH}_{2} \mathrm{Cl}_{2}$ at $\left.298 \mathrm{~K}^{10}\right)$ and $\mathrm{Ru}(\mathrm{bpy})_{2}\left(5,6-\mathrm{Me}_{2} \text { phen }\right)^{2+}\left(\lambda_{\max }=577\right.$ $\mathrm{nm}, \lambda=6.1 \mu \mathrm{s}$ in $\mathrm{MeOH} / \mathrm{EtOH}$ at $77 \mathrm{~K}),{ }^{10}$ showing that the chelating units of PAP, as expected, have the same electronic properties as phen.

The most interesting compound, of course, is the mixed-metal

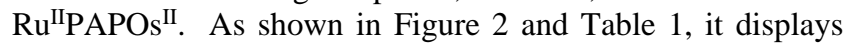
the luminescence bands of both the $\mathrm{Ru}(\mathrm{II})$ and $\mathrm{Os}$ (II) moieties. The luminescence intensity and lifetime of the $\mathrm{Ru}$ (II)-based unit,

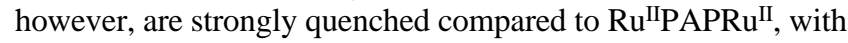

TABLE 1: Luminescence Data

\begin{tabular}{|c|c|c|c|c|c|c|c|c|c|c|}
\hline & \multicolumn{6}{|c|}{$298 \mathrm{~K}^{a}$} & \multicolumn{4}{|c|}{$77 \mathrm{~K}^{b}$} \\
\hline & \multicolumn{3}{|c|}{$\mathrm{Ru}$} & \multicolumn{3}{|c|}{ Os } & \multicolumn{2}{|c|}{$\mathrm{Ru}$} & \multicolumn{2}{|c|}{ Os } \\
\hline & $\begin{array}{l}\lambda_{\max } \\
(\mathrm{nm})\end{array}$ & $\begin{array}{c}\tau \\
\text { (ns) }\end{array}$ & $I_{\text {rel }^{c}}$ & $\begin{array}{l}\lambda_{\max } \\
(\mathrm{nm})\end{array}$ & $\begin{array}{c}\tau \\
(\mathrm{ns})\end{array}$ & $I_{\text {rel }^{c}}$ & $\begin{array}{c}\lambda \\
(\mathrm{nm})\end{array}$ & $\begin{array}{c}\tau \\
(\mu \mathrm{s})\end{array}$ & $\begin{array}{c}\lambda \\
(\mathrm{nm})\end{array}$ & $\begin{array}{c}\tau \\
(\mu \mathrm{s})\end{array}$ \\
\hline $\mathrm{Ru}^{\mathrm{II}} \cdot \mathrm{PAP} \cdot \mathrm{Ru} \mathrm{II}^{\mathrm{II}}$ & 610 & 150 & 100 & & & & 583 & 5.5 & & \\
\hline Os ${ }^{\mathrm{II}} . \mathrm{PAP} . \mathrm{Os}{ }^{\mathrm{II}}$ & & & & 717 & 41 & 100 & & & 709 & 1.0 \\
\hline $\mathrm{Ru}^{\mathrm{II}}$.PAP.Os ${ }^{\mathrm{II}}$ & 609 & 17 & 8 & $712^{f}$ & $41^{d}$ & 95 & 581 & 0.041 & 705 & 1.2 \\
\hline $\mathrm{Ru}^{\mathrm{II}}$.PAP.Os ${ }^{\mathrm{III}} e$ & 609 & 72 & 48 & & & & $f$ & $f$ & $f$ & $f$ \\
\hline
\end{tabular}

${ }^{a}$ Air-equilibrated acetonitrile solution. ${ }^{b}$ Butyronitrile solution. ${ }^{c}$ Excitation was performed at $464 \mathrm{~nm}$, which is an isosbestic point between the Ru-based and Os-based units. ${ }^{d}$ Rise time 15 ns. ${ }^{e} \mathrm{MeCN}-\mathrm{H}_{2} \mathrm{O}$ solution. ${ }^{f}$ Not investigated.

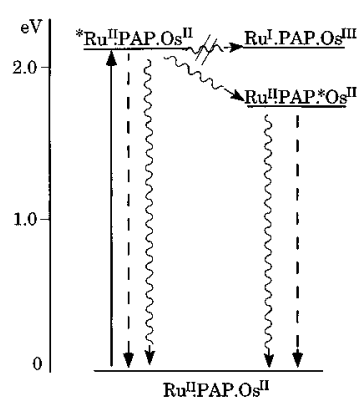

(A)

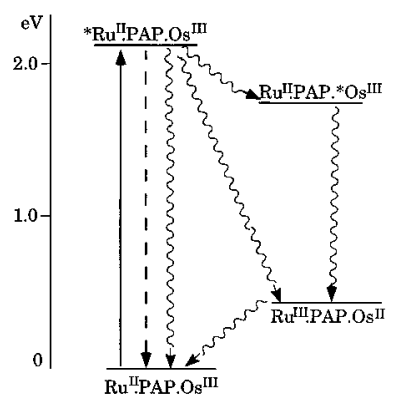

(B)
Figure 3. Energy level diagrams showing the photoinduced energy and electron transfer processes in $\mathrm{Ru}^{\mathrm{II}} \mathrm{PAPOs}^{\mathrm{II}}$ (A) and $\mathrm{Ru}^{\mathrm{II}} \mathrm{PAPO}{ }^{\mathrm{III}}$ (B).

a corresponding sensitization of the Os(II)-based luminescence. Under the experimental conditions used (complex concentration $\left.2.0 \times 10^{-5} \mathrm{M}\right)$, intermolecular energy transfer can be excluded. Therefore the results show that in $\mathrm{Ru}^{\mathrm{II}} \mathrm{PAPO}{ }^{\mathrm{II}}$ an intercomponent (intramolecular) energy-transfer process takes place (Figure $3 \mathrm{~A}$ ), whose rate constant can be obtained from the equation $k$ $=(1 / \tau)-\left(1 / \tau^{\circ}\right)$, where $\tau^{\circ}$ and $\tau$ are the luminescence lifetimes

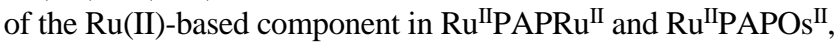
respectively. The values obtained are $5.2 \times 10^{7} \mathrm{~s}^{-1}$ at 298 and $2.4 \times 10^{7} \mathrm{~s}^{-1}$ at $77 \mathrm{~K}$.

Selective oxidation of the Os-based unit of Ru${ }^{\mathrm{II} P A P O s^{\mathrm{II}}}$ by $\mathrm{HNO}_{3}$ converts the emissive Os(II)-based unit into the nonemissive Os(III)-based one. Therefore, the intensity of the luminescence band with $\lambda_{\max }=717 \mathrm{~nm}$ decreases linearly and, as expected, disappears after the addition of 1 equiv of oxidant. In the oxidized $\mathrm{Ru}^{\mathrm{II}}$ PAPOs ${ }^{\mathrm{III}}$ species, the lifetime of the $\mathrm{Ru}-$ based unit is $72 \mathrm{~ns}$ (Table 1). This means that the luminescent $\mathrm{Ru}(\mathrm{II})$-based excited state is quenched by the Os(III)-based component, with rate constant $7.2 \times 10^{6} \mathrm{~s}^{-1}$. Laser flash photolysis experiments showed that the quenching process is accompanied by the growth and successive decrease of an absorption band with maximum at $650 \mathrm{~nm}$, characteristic of the Os(II) moiety. ${ }^{11}$ This shows that the quenching leads to the formation of the $\mathrm{Ru}^{\mathrm{III}} \mathrm{PAPO} \mathrm{s}^{\mathrm{II}}$ intervalence-transfer product, either directly or (less likely) via a first energy-transfer step (Figure 3B). ${ }^{12}$ The Ru${ }^{\text {III PAPOs }}{ }^{\mathrm{II}}$ species then decays to its ground-state isomer $\mathrm{Ru}^{\mathrm{II} P A P O{ }^{\mathrm{III}}}$ with rate constant $8.3 \times 10^{3}$ $\mathrm{s}^{-1}$.

A detailed and comparative discussion of these data and of those obtained for similar complexes will be given elsewhere. ${ }^{14}$ Two very interesting features, however, can already be pointed out: (i) the lifetime of the intermediate electron-transfer product $\mathrm{Ru}^{\mathrm{II} P A P O s^{\mathrm{III}}}$ is very long $(130 \mu \mathrm{s})$; (ii) for the first time in a dinuclear $\mathrm{Ru} / \mathrm{Os}$ system, ${ }^{2}$ the rate constant of energy transfer 
from the $\mathrm{Ru}(\mathrm{II})$ to the $\mathrm{Os}(\mathrm{II})$ unit is faster than the rate of electron transfer from the $\mathrm{Ru}(\mathrm{II})$ to the $\mathrm{Os}(\mathrm{III})$ unit.

Acknowledgment. We would like to thank Mr. M. Minghetti for technical assistance. This work was supported by the Italian MURST and CNR (Progetto Strategico Tecnologie Chimiche Innovative) and by the Swiss National Science Foundation.

\section{References and Notes}

(1) (a) University of Bologna. (b) Instituto FRAE-CNR. (c) Universität Freiburg.

(2) Balzani, V.; Juris, A. Venturi, M.; Campagna, S.; Serroni, S. Chem. Rev. 1996, 96, 759 .

(3) (a) Balzani, V.; Moggi, L.; Scandola, F. In Supramolecular Photochemistry; Balzani, V., Ed.; Reidel: Dordrecht, The Netherlands, 1987; p 1. (b) Balzani, V.; Scandola, F. Supramolecular Photochemistry; Horwood: Chichester, U.K., 1991. (c) Fabbrizzi, L., Poggi, A., Eds. Transition Metals in Supramolecular Chemistry; Kluwer: Dordrecht, The Netherlands, 1994. (d) Lehn, J.-M. Supramolecular Chemistry; VCH: New York, 1995. (e) Astruc, D. Electron Transfer and Radical Processes in Transition-Metal Complexes; VCH: New York, 1995.

(4) (a) Crosby, G. A.; Watts, R. J.; Carstens, D. H. Science, 1970, 170, 1195. (b) Meyer, T. J. Pure Appl. Chem. 1986, 58, 1193. (c) Juris, A.; Balzani, V.; Barigelletti, F.; Campagna, S.; Belser, P.; von Zelewsky, A. Coord. Chem. Rev. 1988, 84, 85. (d) Kalyanasundaram, K. Photochemistry of Polypyridine and Porphyrin Complexes; Academic Press: London, U.K., 1992.

(5) Sauvage, J.-P.; Collin, J.-P.; Chambron, J.-C.; Guillerez, S.; Coudret, C.; Balzani, V.; Barigelletti, F.; De Cola, L.; Flamigni, L. Chem. Rev. 1994 94, 993.

(6) Constable, E. C. Prog. Inorg. Chem. 1994, 42, 67.
(7) Belser, P.; Bernhard, S. Synthesis 1996, 192.

(8) Belser, P.; von Zelewsky, A.; Frank, M.; Seel, C.; Vögtle, F.; De Cola, L.; Barigelletti, F.; Balzani, V. J. Am. Chem. Soc. 1993, 115, 4076. 2683.

(9) Elfring, W. H., Jr.; Crosby, G. A. J. Am. Chem. Soc. 1981, 103 ,

(10) Caspar, J. V.; Meyer, T. J. Inorg. Chem. 1983, 22, 2444.

(11) De Cola, L.; Balzani, V.; Barigelletti, F.; Flamigni, L.; Belser, P.; von Zelewsky, A.; Frank, M.; Vögtle, F. Inorg. Chem. 1993, 32, 5228.

(12) The maximum of the lowest energy absorption band for Os(bpy) $3^{3+}$ is at $2.02 \mathrm{eV} .{ }^{13}$ The zero-zero transition is expected to be $0.2-0.3 \mathrm{eV}$ lower in energy.

(13) Bryant, G. M.; Fergusson, J. E. Aust. J. Chem. 1971, 24, 275.

(14) The most pertinent $\mathrm{Ru}(\mathrm{II}) / \mathrm{Os}$ (II) and $\mathrm{Ru}(\mathrm{II}) / \mathrm{Os}$ (III) systems for a comparative discussion are those described in refs 8 and 11 and in the following papers: (a) Furue, M.; Yoshidzumi, T.; Kinoshita, S.; Kushida, T.; Nozakura, S.; Kamachi, M. Bull. Chem. Soc. Jpn. 1991, 64, 1632. (b) Vögtle, F.; Frank, M.; Nieger, M.; Belser, P.; von Zelewsky, A.; Balzani, V.; Barigelletti, F. De Cola, L.; Flamigni, L. Angew. Chem., Int. Ed. Engl. 1993, 32, 1643. (c) Barigelletti, F.; Flamigni, L.; Balzani, V.; Collin, J.P.; Sauvage, J.-P.; Sour, A.; Constable, E. C.; Cargill Thompson, A. M. W. J. Am. Chem. Soc. 1994, 116, 7692. (d) Furue, M.; Maruyama, K.; Kanematsu, Y.; Kushida, T.; Kamachi, M. Coord. Chem. Rev. 1994, 132, 201. (e) Beley, M.; Chodorowsky, S.; Collin, J.-P.; Sauvage, J.-P.; Flamigni, L.; Barigelletti, F. Inorg. Chem. 1994, 33, 2543. (f) Belser, P.; Dux, R.; Baak, M.; De Cola, L.; Balzani, V. Angew. Chem., Int. Ed. Engl. 1995, 34 595. (g) Grosshenny, V.; Harriman, A.; Ziessel, R. Angew. Chem., Int Ed. Engl. 1995, 34, 1100. (h) Barigelletti, F.; Flamigni, L.; Balzani, V.; Collin, J.-P.; Sauvage, J.-P.; Sour, A. New J. Chem. 1995, 19, 793. (i) De Cola, L.; Balzani, V.; Barigelletti, F.; Flamigni, L.; Belser, P.; Bernhard, S. Recl. Trav. Chim. Pays-Bas 1995, 114, 534. (j) Frank, M.; Nieger, M.; Vögtle, F.; Belser, P.; von Zelewsky, A.; De Cola, L.; Balzani, V.; Barigelletti, F.; Flamigni, L. Inorg. Chim. Acta 1996, 242, 281.

JP962366X 